\title{
English Idioms in Some Nigerian Print Media: of Norm and Deviation
}

\author{
Gabriel A. Osoba ${ }^{1}$, Ph.D \\ ${ }^{1}$ Department of English, Lagos State University, Ojo, Lagos, Lagos State, Nigeria \\ Correspondence: Gabriel A. Osoba, Ph.D, Department of English, Lagos State University, Ojo, Lagos, Lagos State, \\ Nigeria. E-mail: gabosoba002@yahoo.com \\ Received: April 16, 2014 \\ Accepted: May 9, 2014 \\ Online Published: May 14, 2014 \\ doi:10.5430/elr.v3n1p46 \\ URL: http://dx.doi.org/10.5430/elr.v3n1p46
}

\begin{abstract}
The use of English idioms in news report is a common feature in Nigeria print media. In this paper, an attempt is made to examine the English idioms used in some Nigerian newspapers based on the concept of style as deviation from the norm. The paper evaluates the extent to which newspaper writers are faithful to the original idioms. In the data collected for comparison and analysis, it is discovered that the idioms have undergone modifications in the Nigerian press, breaking the rule of fixed collocation. The paper raises the question as to whether these deviant English idioms should be accepted or rejected. The paper posits that these deviations may become the norm if unchecked.
\end{abstract}

Keywords: English idioms, Nigerian print media, Norm, Deviation, Variation

\section{Introduction}

The press, especially the print media, has a lot of influence on the society. It is recognised as a strong force in moulding opinions and influencing decisions on issues of national importance. Retired General T. Y. Danjuma once confessed in a newspaper interview (Daily Sun; May 11, 2006, pg. 19)

I am happy that you journalists are leading in the fight against the amendment of the constitution to allow for a third term. When third term is dead and buried, the gold medal and the national honour for the victory against this undemocratic move would be awarded to you the Nigerian Journalists.

The pen of the journalists is indisputably a potent weapon for good or for ill. What is written in the print media often registers indelibly on the mind of the reading public. It is expected that not only the information but the language used to convey it be handled with deliberate carefulness to avoid misleading the reading public. As Dadzie and Awonusi (2004: 98) express, 'the print media has a responsibility to provide acceptable usage in structure and semantics since many people read nothing but newspapers after they leave school'.

This paper attempts to identify and highlight the modification which some English idioms have been subjected to in the Nigerian Print media, from the perspective of style as deviation from the norm

\section{Historical/ Theoretical Background and Methodology}

This section provides the historical/theoretical background of the paper as well as its methodology.

\subsection{Historical/Theoretical Background}

The history of English in Nigeria has been traced to the cross-cultural contact between Europe and Nigeria, initially through trade and later, colonisation. (Ogu 1992, Bamgbose 1995, Dadzie and Awonusi 2004). Though it is not the 'language of the soil', English has taken firm roots in the speech community'. Prior to the importation of English into Nigeria, indigenous languages existed and still exist in the society. The result of the contact with English is that it has undergone and is still undergoing changes to reflect the multilingual and multicultural Nigerian society.

Nigerian English as a variant of English is different from the British or American Standard English in grammar, lexis and phonology. Nigerian English has generated a lot of lively interest among scholars. The issue is no longer whether Nigerian English exists or not but rather on influences, characteristics, parameters for standardisation etc. Nigerian English has been examined in many ramifications including its phonology (Adetugbo, Awonusi Banjo), grammar (Dadzie, Egbe), lexis (Adejare Daramola,), stylistics (Ajeigbe, Jowitt). The term domestication has emerged in the context of English in Nigeria to connote 'home-grown', indigenized English (Adegbija 2004:20). The 
influence of English in the Nigerian environment is wide and varied - political, educational, linguistic, sociolinguistic, cultural. English will continue to be needed for purposes of general participation in the social process. It is the language of education, government, politics, law, the mass media. Formal communication depends on English in practically every facet of life. Nigeria depends on the English Language in many communicative domains.

The question which has engaged the attention of scholars in various ways in recent years centres on the appropriateness and inappropriateness of English Language use in Nigerian context. Language is one area of social life with a large collection of norms. There are rules, conventions and regulations guiding the use of language. A norm has to do with what is expected of a typical member of the language community.

Adeyanju (2009) describes kachru(1986) 'three circles theory on the spread of English as follows: the inner circle ( where English is used as L1 e.g. U.K,U.S.A, Australia), the outer circle (where English is used as L2 e.g. Nigeria, Ghana ,Kenya ,India etc.) and the expanding circle (consisting of users of English as a foreign language e.g. Brazil , Italy, Morocco etc ); the inner circle's English as a norm providing circle, the outer circle as norm developing. Norms are, however, not static as new norms develop overtime and from generation to generation.

Language deviation refers to the use of language outside the range of normal language. Stylistics helps to identify and discuss how and why a text has deviated. Deviation in stylistics is concerned with the departure from expected forms of language. According to Mukarovsky (2003:226) 'the violation of the norm of the standard...is what makes possible the poetic utilization of language.' Deviation may occur at any level of description- graphological, phonological, syntactic and lexico-semantic.

An idiom is an expression or a phrase whose meaning is difficult or sometimes impossible to guess by looking at or adding together the meaning of the individual words is contains. Wales (1997:231) describes idioms as follows:

... in linguistics idioms most usually denote phrases or strings of words which are idiosyncratic (idiomatic) in that their language- specific, not easily translated into another language and that their meaning is not easily determined from the meanings of their constitutive parts. In English such phrases are characteristically fixed in COLLOCATION. (Capitals hers)

Though idioms are often metaphorical and colourful expressions or sayings, the words constituting them are fixed. This paper is an examination of the forms of deviation in English idioms in some Nigerian newspapers in relation to whether they can be accepted or not as variants in the Nigerian context. As Lawal (2003:20) explains,

A critical distinction between variation and deviation as two sociolinguistic/ stylistic concepts is that whereas the speaker or writer constrains himself or herself within the structural limits of the language to select particular variant forms appropriate for his/her communicative needs, deviant forms, in stylistic terms, are reconstructed from the structural resources of the language to extend the frontiers of current usages.

The question that arises in the use of English idioms in Nigeria print media is whether the idioms are variations of forms to 'extend the frontiers of current usages' or are deviations from the original idioms as a result of ignorance, carelessness or 'little' learning.

\subsection{Methodology}

This paper draws samples for the purpose of exemplification of English idioms from some Nigerian newspapers which the author kept some years ago. The focus is on the English idioms in the newspapers rather than their periods of publication. The samples are presented as data, analysed and discussed below to draw attention to the standard English idioms and the deviations/modifications in some Nigerian print media.

\section{Data Presentation}

The data for this study are from different Nigerian newspapers. Nine samples from the print media which contain well- known English idioms are examined as representatives of English idioms in Nigerian newspapers. This paper utilizes these samples for the purpose of analysis and discussion in relation to norm and deviation.

Samples

Sample1: 'to stir up the hornet's nest'

'Professor Ndi Okereke Oniyinke, Director- General of the Nigerian Stock Exchange may have stirred the hornets' nest with her declaration that the addition of Nigerian investors to the internet, CNN and other international news networks was the primary cause of the crash of the Nigerian stock market', 'Daily Sun, July 23,2009'. 
Sample :2 'handwriting on the wall'

'We know with the handwriting on the wall that there is every evidence that the President and some of his governors are working seriously for a third term in office'. 'Daily Sun, January 2, 2006'.

Sample 3: 'under locks and keys;

'Many of our industries are operating below 25 percent capacity utilization or they are under lock and keys. 'The Comet's opinion page, July 19, 2005.

Sample 4: 'not towing this same line'

'By not towing this same line, under the present circumstance, the Independent Electoral Commission (INEC) would definitely have problems in clearing itself of the charge of deliberately seeking to exclude some of the political parties from political activities' Tribune Editorial, 'March 8, 2004'.

Sample 5: 'running neck- to- neck'

'...running neck-to-neck with the story of Rashidi Ladoja, the latest victim of the politic of recrimination in Africa's most problematic political party, the people's Democratic party (PDP) 'The Guardian's opening page, 'January 13, 2006'.

Sample: 6 'pointing accusing fingers'

'weeks after the healing crusade of pastor Benny Hinn, the dust raised by the aftermath of the crusade is yet to settle with parties including men of God pointing accusing fingers at one another over financial impropriety'.' Nigerian Tribune's sidelines July, 12, 2005'.

Sample 7: 'more grease to your elbow'

'May God continue to guide your efforts to improve the living condition of the people of the state. More grease to your elbow.' 'Advertorial, The Punch, March 29,2003'.

Sample 8 : 'to make noise'

'Vanguard believes that for now, the only thing to do now is not to make noise as the current condition 'Vanguard comment, May 17, 2004.

Sample 9: 'on the street'

'The scarcity (of newsprint ) has now built into an industrial crisis. Newspapers are struggling to find ... any quality of paper of whatever hue and colour to enable them remain on the street'. 'The Guardian op-ed page, September 21, 2005 '.

\section{Data Analysis and Discussion}

'To stir up a hornet's nest's means 'to create trouble'. It is an idiom which is used in the context of ' a difficult situation in which a lot of people get very angry'. The deviation arises from the substitution of the article ' $a$ ' for the determiner 'the' by the newspaper reporter in sample 1 '...may have stirred the hornets' nest with her declaration that....' There is also the placing of an apostrophe before 's' rather than after it as well as the omission of the preposition 'up'.

The saying' writing on the wall' is written as the 'handwriting on the wall' in sample2. The saying originates from the Bible story' in which strange writing appeared on a wall during a feast given by king Belshazzar predicting Belshazzar's death and fall of the city.' The modification is the addition of 'hand' to 'writing'. The saying is used to describe a situation in which there are signs that something is going to have problems.

The original idiom 'under lock and key ' is found as 'under locks and keys' in sample 3. 'lock and key' are in the plural version in the reporter's use of idiom, as opposed to convention. To 'keep or put something or somebody under lock and key' is to have the thing or person 'locked up safely somewhere'.

'To toe the line' in sample 4 is an idiom which means to 'conform/obey the rules or keep to accepted ideas'. The idiom undergoes a transformation to read as 'towing this same line, in sample 4 . The problem here is the inability to distinguish between 'toe' and 'tow' which are homophones.

In sample 5, the idiom 'to run neck and neck' becomes 'running neck-to-neck'. Neck- and neck' is modified as, 'neck-to-neck 'by the reporter.' To run neck and neck' means 'level with somebody in a race or competition. The sense of 'equal' or 'level' is implied in sample 5 but the reporter has changed the fixed idiom. to 'neck to neck'. 
Sample 6 is to demonstrate the change of an idiom from 'point a/the finger '(at somebody) to 'to pointing accusing fingers'. 'finger' becomes 'fingers'. In sample 6, finger has changed from singular to plural form. 'To point a/the finger' means .to accuse somebody of doing something' or 'to blame somebody'.

The idiom, 'more power to your elbow' is changed to 'more grease to your elbow' in sample 7. The fixed phrase 'more power to your elbow' meaning 'more strength/force to your efforts' is used to encourage somebody. 'Grease is substituted for 'power'. In samples 8 and 9, 'a' is omitted in the expression 'to make a noise' and 'on' is substituted for 'in' 'in the street' respectively. All the nine samples selected show a deviation in one form or another from the original English idioms.

For ease of comparison, the English idioms and the newspaper's versions are itemized as follows:

Sample: English idioms (Norm) Nigerian newspapers (Deviation)

1. 'to stir up a hornet's nest

2. 'writing on the wall'

3. 'lock and key'

4. 'to toe the line'

5. 'to run neck and neck'

6. 'to point a/the finger'

7. 'more power to your elbow'

8. 'to make a noise'

9. 'in the street'
'... stirred the hornets' nest'

'...handwriting on the wall'

'locks and keys'

'towing this same line'

'running neck-to-neck'

'pointing accusing fingers'

'more grease to your elbow'

'to make noise'

'on the street'

One common feature among all the idioms in samples 1-9 is that they all violated the rule of fixed collocation. Idioms are often fixed phrases that are not susceptible to lexical substitution, re-ordering or alternation. This is not the case in sample 1 where 'the' is substituted for 'a', sample 4 where 'tow' is substituted for 'toe', sample 7 , 'grease' for 'power'. The single forms of the 'lock and key' are changed to the plural forms in sample 3.

Sample 4 presents a case of error of use of a wrong expression 'towing the same line' for 'toe' the line. The source of the problem is that 'toe' and 'tow' are homophones-similar sound but with difference in meaning and spelling. The problem with sample 9 is with the choice of preposition 'on' instead of 'in'. The tendency is to think that since 'on' goes with 'the road' and 'the way' as in 'on the road' and 'on the way' respectively, it should also keep company with the related word, 'street'. Language is illogical : the correct thing is to say or write is 'in the street'. 'Writing on the wall' is British English while 'handwriting on the wall' in sample 2 is American English. Though both forms of English are acceptable, the reporter is expected to be consistent in his use of British English, the form that is common in Nigerian newspapers 'More grease to your elbow' (sample 7) to imply 'bravo', is a distortion of the British expression 'more power to your elbow'

The norm is expected but the actual behaviour does not conform in the selected samples. The issue is whether the kinds of deviation from the original idioms are caused by ignorance, carelessness or the need for diversity or variation. For most of the samples used in this paper for illustration, the deviations may be a result of a gap in the reporters' knowledge of English which needs to be filled (samples 1,2,3,4,6,10) . Others may be due to lack of revision of what is written to eliminate spelling errors. The influence of Americanisms might have dictated the choice of 'handwriting' rather than 'writing'. Journalists are expected to know the differences in spelling, lexis and syntax between British and American English.

\section{Conclusion}

This paper has examined English idioms in some Nigerian newspapers and pointed out how they have deviated from the original versions. The deviations undermined the rule of fixed collocation and render the idioms abnormal, a distortion of the original fixed phrases. The import of this paper is to draw attention to the need for journalists to be more careful with the written word, especially idioms which are 'characteristically fixed in collocation' (Wales 1997). 


\section{References}

Adegbija, E. (2004). 'The Domestication of English in Nigeria'. A Festchrift in honour of Abiodun Adetugbo' eds S Awonusi and E.A Babalola. Lagos: University of Lagos Press.

Adeyanju, Dele. (2009). "'Idiomatic Variation in Nigerian English: Implications for Standardization in the Context of Globalization 'Journal of English Studies Vol. 7 pp 7-22.

Dadzie, ABK \& S.Awonusi, .(eds). (2004). Nigerian English: Influence and Characteristics. Lagos : Concept Publication.

Kachru, B. (1986). The Alchemy of English; The Spread, Functions and Models of non-native Englishes. Oxford : Oxford Pergamon Books.

Lawal, A. (2003). Stylistics in Theory and Practice. Ilorin: Paragon Book Ltd.

Mukarovsky, Jan. (2003). Standard Language and Poetics Language in The Routledge Language and Cultural Theory Reader edited by Lucy Burke, Tony Crowley and Alan Girvin. Cornwall: TJ International Ltd.

Wales, Katie. (1997). A Dictionary of Stylistics. London and New York: Longman. 